\title{
Impact of Working Capital Management on Firm Performance in Different Business Cycles: Evidence from Vietnam*
}

\author{
Co Trong NGUYEN ${ }^{1}$
}

Received: September 10, 2020 Revised: November 02, 2020 Accepted: November 16, 2020

\begin{abstract}
This study was conducted on financial data of 38 economic groups listed on Vietnam's stock market for the period 2009 - 2019 and it aims to provide an empirical evidence on the impact of working capital management policy on performance in all phases of the economic cycle of Vietnamese economic groups. The study uses FGLS estimation method with 2 dependent variables ROA, GOP, independent variables including INV, AR, AP, CCC, dummy variable representing different phases of the economic cycle, variables Control includes CAT, CR, LEV, SZ, GR. Research shows that the greater the level of investment by companies in liquid assets corresponding to a certain level of activity (shown by average days of inventory (INV), average days of collection. (AR), cash flow cycle (CCC)) the lower the rate of return on assets. The study also provides additional evidence of the negative effects of economic crisis on the performance of economic groups. The study also shows that the number of short-term asset cycles has a positive impact on operational efficiency, and the level of debt use has a negative impact on operational efficiency. This result implies that the managers of economic groups can increase the efficiency of businesses through a reasonable working capital policy.
\end{abstract}

Keywords: Working Capital Management, Business Cycles, Economic Groups, Vietnam

JEL Classification Code: G30, M40, M41

\section{Introduction}

Working capital management along with investment and long-term funding decisions are the key financial decisions of a business. Working capital policy, in theory, affects risks and returns, thereby affecting the value of the business. Horne and Wachowicz (2008) suggest that an extensive liquid asset investment helps firms maintain good solvency and ensure better expected returns, but the return is often not high. Because a firm has to invest a lot of capital, and vice versa, a tight working asset investment policy can bring a

\footnotetext{
*Acknowledgements:

The author is thankful to the Academy of Finance for funding this research. I would like to thank the anonymous referees for their helpful comments and suggestions.

${ }^{1}$ First Author and Corresponding Author. Director, Academy of Finance, Vietnam [Postal Address: 58 Le Van Hien Road, Bac Tu Liem District, Hanoi, 130500, Vietnam] Email: nguyentrongco.aof@gmail.com

(C) Copyright: The Author(s)

This is an Open Access article distributed under the terms of the Creative Commons Attribution Non-Commercial License (https://creativecommons.org/licenses/by-nc/4.0/) which permits unrestricted non-commercial use, distribution, and reproduction in any medium, provided the original work is properly cited.
}

high rate of return but it comes with liquidity risk and great uncertainty in returns is. expected.

Working capital management involves planning and controlling the company's current assets and short-term liabilities. Firms can pursue different working capital policies to achieve different levels of return and risk exposure, managers need to consider the trade-off between expected returns and risks before determining an optimal level of working capital, which is the level of working capital that maximizes the enterprise's value, not the minimum working capital.

The crises, with the most obvious sign of a sharp decline in sales, limit the company's revenue and margins, and then affect working capital management. The 2008-2009 global economic downturn has brought a new perspective on working capital management policy in companies. Companies find that an unusual open economy has an impact on their operations because it plays an important role in product demand as well as in the financial decisions of firms.

Economic group is a company model for large-scale enterprises operating in the economy of each country. The formation and development of economic groups in Vietnam stems from the need for development of enterprises in the 
market economy. Faced with competitive pressure, companies tend to merge or link together into groups to improve their competitiveness. However, not all economic groups can survive and develop. Operational efficiency of economic groups has always been an important issue that is currently a concern for the interests and influence of economic corporations on a country. Working capital management policy is one of the important factors affecting the performance of businesses in general and economic groups in particular.

This article aims to examine the relationship between working capital policy and the performance of economic groups in Vietnam through a study of economic groups listed on the Vietnamese stock market, based on the financial data for the period from 2009 to 2019.

\section{Literature Review}

Many empirical studies on the relationship between working capital management and corporate performance have been carried out in many countries. However, most studies show an inverse relationship between profitability and cash conversion cycle as well as inventory days and collection periods. Research results also show that lowpaying companies tend to pay for purchases more slowly. Some case studies can be mentioned such as by Deloof (2003) who studied large Belgian companies for the period 1992 - 1996; Lazaridis and Tryphonidis (2006) studied 131 companies on the Athenian Stock Exchange for the period 2001-2004; Garcia-Turuel and MartinezSolano (2007) studied Spanish SMEs for the 1996-2002 period; Dong and $\mathrm{Su}$ (2010) studied 130 listed companies on the Vietnamese stock market for the period 2006 - 2008.

Most studies were conducted to understand the relationship between working capital management with the profitability of enterprises. All studies choose the gross profit ratio (Revenue - Cost of goods sold) / (Total assets - Financial assets) as the representative for profitability; average inventory period, average collection period, cash flow cycle represent working capital policy; The variables of size and financial leverage are often included as control variables.

Currently, only a handful of studies have examined the impact of the economic cycle on working capital management. The case study was done by Merville and Tavis (1973), the authors examined the relationship between corporate working capital policy and the economic cycle. Several studies have shown a link between working capital and firm profitability in different phases of the economic cycle: Enqvist et al (2014), Mielcarz et al. (2018), and Oseifuah (2018). The results of the studies show that, in the financial crisis, profitability has a significant negative relationship with the collection period but positively correlates with the inventory rotation period. After a period of financial crisis, the relationship between returns and deadlines reverses and becoming a positive one.

\section{Research Method}

\subsection{Research Model}

The research model construction is done on the basis of the results of an overview of researches on similar topics at home and abroad. In which, the variable representing the performance of economic groups is measured by 2 indicators of return on total assets (ROA) and rate of return on operating assets (GOP) as used in a lot of other studies.

$$
\begin{aligned}
\text { Model 1: } \mathrm{ROA}= & \beta 0+\beta 1 * \mathrm{INV}+\beta 2 * \mathrm{AR}+\beta 3 * \mathrm{AP} \\
& +\beta 4 * \mathrm{CCC}+\beta 5^{*} \mathrm{Dummy}+\beta 6^{*} \mathrm{CAT} \\
& +\beta 7 * \mathrm{CR}+\beta 8^{*} \mathrm{LEV}+\beta_{9}^{*} \mathrm{SZ} \\
& +\beta_{10}^{*} \mathrm{GR}+\mathrm{u} \\
\text { Model 2: } \mathrm{GOP}= & \beta 0+\beta 1 * \mathrm{INV}+\beta 2 * \mathrm{AR}+\beta 3 * \mathrm{AP} \\
& +\beta 4 * \mathrm{CCC}+\beta 5 * \mathrm{Dummy} \\
& +\beta 6 * \mathrm{CAT}+\beta 7 * \mathrm{CR}+\mathrm{LEV} \\
& +\beta 9 \beta 8 * \mathrm{SZ}+\beta 10 * \mathrm{GR}+\mathrm{u}
\end{aligned}
$$

The following is a definition of variables in the model:

\subsection{Data and Research Methods}

\section{Research data}

The sample includes 38 economic groups listed on the Vietnamese stock market: Hanoi Stock Exchange (HNX) and Ho Chi Minh City Stock Exchange (HOSE) for the period 2009-2019. Statistical data is collected from the financial statements of the companies.

\section{Research methodology}

The study used balance sheet data of 38 economic groups for the period 2009-2019. Therefore, firstly regression according to 3 methods for balance table data are: the least squares method (pooled OLS), the estimation method according to the fixed effects model (FEM) and the estimation method. model of random effects (REM). Next, to choose the appropriate estimation method for the research data, tests will be performed such as: $F$ test to choose between pooled OLS and FEM, LM test (Breusch-Pagan Lagrange Multiplier) between pooled OLS and REM, and the Hausman test between FEM and REM.

However, the cointegration test and the variance test for estimates according to the FEM and REM model in each case give violation results on the phenomenon of cointegration and the variance of variation change. Therefore, to overcome the above problem, the author conducted an estimate according to the FGLS model in order to achieve an efficient, stable and unbiased estimate and reliable test results. 
Table 1: Synthesize how to calculate variables and expected signs in the model

\begin{tabular}{|l|l|l|c|}
\hline No & \multicolumn{1}{|c|}{ Variables } & \multicolumn{1}{|c|}{ Calculation } & Mark expected \\
\hline 1 & ROA & Profit after tax / Total assets & $\begin{array}{c}\text { Dependent } \\
\text { variable }\end{array}$ \\
\hline 2 & GOP & (Revenue - Cost of goods sold) / (Total assets - Financial assets) & $\begin{array}{c}\text { Dependent } \\
\text { variable }\end{array}$ \\
\hline 2 & INV & Logarit (Inventory / Cost of goods sold Average daily) & - \\
\hline 3 & AR & Logarithms (Receivables / Average daily revenue) & - \\
\hline 4 & AP & Logarithms (Payables / Average daily cost of goods sold) & + \\
\hline 5 & CCC & INV + AR - AP & - \\
\hline 6 & Dummy & $\begin{array}{l}\text { Valuable is 1 in 5 years (2009-2013) when the Vietnamese economy was } \\
\text { affected by the global economic recession; 0 in the years of economic }\end{array}$ & - \\
\hline 7 & CAT & Recovery (2014-2019) & + \\
\hline 8 & CR & AssetsCurrent Assets / Short-term Liabilities & - \\
\hline 9 & LEV & Liabilities / Total Assets & - \\
\hline 10 & SZ & Logarithm (total assets) & - / + \\
\hline 11 & GR & (Revenue year t - Revenue year t-1) / Revenue year t-1 & $-/+$ \\
\hline
\end{tabular}

\section{Research Results}

Table 2 presents the results of model 1 research with the dependent variable ROA.

Multicollinearity test results show that the magnification coefficient of VIF variance are $<10$, the model has no multicollinearity phenomenon. The mean VIF is 2.98, which indicates that the possibility of multicollinearity is not significant. The White test indicates that the model has heterogeneity ( $\mathrm{p}$-value $<5 \%$ ) and the Breusch and Pagan Lagrangian Multiplier test for random effects results (Table 2) rejected the null hypothesis that the Pooled OLS model was appropriate. Following the results from the Hausman test (P-value $=0.0014<0.05)$, selecting the appropriate model is FEM, the author proceeds to overcome the discovered defects of the model by GLS method.

The empirical results of model 2 are shown in Table 3. As the results of regression analysis show that the value of VIF coefficient is less than 10 , there is a multi-collinear phenomenon. The maximum VIF is 2.98, which indicates that the possibility of multicollinearity is not significant.

The White test indicates that the model has heterogeneity ( $p$-value $<5 \%$ ) and the Breusch and Pagan Lagrangian Multiplier test for random effects results (Table 3) rejected the null hypothesis that the Pooled OLS model was appropriate. Following the results from the Hausman test (P-value $=$ $0.2428>0.05$ ), selecting the appropriate model is REM, the author proceeds to overcome the discovered defects of the model by GLS method.
The model 1 regression results show that there is a significant negative relationship between average days of receivable (INV) and ROA, which is consistent with theory and previous studies that if the average number of days receivable is shorter then it means that the receivable is well managed and rotates quickly, which increases the operational efficiency of the economic groups. Research results also show a statistically significant positive relationship between average days payables (AP) and ROA, which is consistent with the previous theories and studies. There exists a positive relationship between the cash flow cycle (CCC) and ROA, which is consistent with the theories and the previous studies, the higher the cash conversion cycle, the faster the cash flow, contributing to high performance of economic groups. The research results have provided more evidence of the impact of the economic cycle phases on performance, the years affected by the economic crisis negatively affect the performance of corporations and the economy. The results also showed a statistically significant positive relationship between ROA and short-term asset turnover (CAT) and revenue growth (GR). Debt utilization (LEV) has a negative relationship with ROA and is statistically significant. These results are consistent with those of studies done previously in other countries, such as the study of Deloof (2003); Ionnis and Lazaridis (2006); Garcia-Turuel and MartinezSolano (2007); Dong (2010), Enqvist et al (2014), Mielcarz et al (2018), Pham et al. (2020), Oseifuah (2018) and Ngwenya (2012), Pattiruhu and Paais (2020) show that ROA has a positive and significant impact on dividend policy. 
Table 2: Regression results of model 1

\begin{tabular}{|c|c|c|c|c|}
\hline \multirow{2}{*}{ Variable } & \multirow{2}{*}{ VIF } & \multicolumn{3}{|c|}{ Regression coefficients } \\
\hline & & POLS & FEM & REM \\
\hline INV & 3.61 & $-0.00109 *$ & -0.00252 & -0.00303 \\
\hline AR & 6.38 & $-0.0239 * *$ & -0.0156 & $-0.0226 * *$ \\
\hline AP & 1.92 & 0.00778 & 0.0128 ** & 0.00993 * \\
\hline $\mathrm{CCC}$ & 6.84 & 0.0179 * & -0.0000307 & 0.00905 \\
\hline Dummy & 1.19 & 0.0173 ** & 0.00874 & 0.0160 ** \\
\hline CAT & 3.89 & $0.0214^{* * *}$ & $0.0225^{* * *}$ & 0.0192 ** \\
\hline CR & 1.52 & $-0.00405 * * *$ & -0.000254 & -0.00162 \\
\hline LEV & 1.76 & $-0.170^{* * *}$ & $-0.225^{* * *}$ & $-0.186 * * *$ \\
\hline SZ & 1.66 & **0.00567 & -0.00287 & 0.00529 \\
\hline GR & $1: 04$ & $0.00715^{* *}$ & 0.00398 & 0.00491 * \\
\hline Cons & & -0.0512 & 0255 & 0.00578 \\
\hline \multirow[t]{2}{*}{$N$} & & 403403 & & 403 \\
\hline & & 0281 & 0201 & \\
\hline $\begin{array}{l}\text { R-sq- } \\
\text { significance }\end{array}$ & & $\begin{array}{l}\mathrm{F}(10,392) \\
\quad=15: 36\end{array}$ & $\begin{array}{l}\mathrm{F}(10.355) \\
\quad=8.95\end{array}$ & $\begin{array}{c}\text { Wald chi2 } \\
(10)=97.42\end{array}$ \\
\hline White test & & \multicolumn{3}{|c|}{$\begin{array}{c}\text { Chi2 }(64)=86.53 \text { Prob }>\text { Chi2 }= \\
0.0319\end{array}$} \\
\hline LM test & & \multicolumn{3}{|c|}{$\begin{array}{rr}\text { Chibar2 }(38)=1718.96 & \text { Prob> } \\
\text { chibar2 }=0.0000 & \end{array}$} \\
\hline $\begin{array}{l}\text { Hausman } \\
\text { test }\end{array}$ & & \multicolumn{3}{|c|}{$\begin{array}{r}\text { Chi2 }(10)=28.70 \\
0.0014\end{array}$} \\
\hline $\begin{array}{l}\text { Wooldridge } \\
\text { test }\end{array}$ & & \multicolumn{3}{|c|}{$F(1,37)=11.970$} \\
\hline
\end{tabular}

Note: $\left.\left({ }^{*}\right),\left({ }^{* *}\right),{ }^{* * *}\right)$ represent for the significant level at $1 \%, 5 \%$ and $10 \%$, respectively.

Table 4 above is the results of model 2 regression, with dependent variable is GOP. The sign of the coefficient of variables AR, Dummy, CAT, LEV is similar to the results of model 1. Ali and Faisal (2020) show that the debtequity ratio is not improving profitability, utilization of resources of petrochemicals companies of Saudi Arabia. The above results show a statistically significant negative relationship between ROA and AR. This means that the sooner economic groups collect money from customers, the higher the profitability of economic groups, which is also consistent with the theory and previous studies that a credit policy tightening will increase profit margins for economic groups as long as the policy does not cause a loss of revenue. The effects of periods in the economic cycle are similar to model 1 . Besides, the cash flow cycle has the same impact on the GOP but is not statistically significant.
Table 3: Regression results of model 2

\begin{tabular}{|c|c|c|c|c|}
\hline \multirow{2}{*}{ Variable } & \multirow{2}{*}{ VIF } & \multicolumn{3}{|c|}{ Regression coefficients } \\
\hline & & POLS & FEM & REM \\
\hline INV & 3.61 & -0.000450 & 0.00873 & -0.00830 \\
\hline AR & 6.38 & $-0.0540 * * *$ & -0.00918 & -0.0254 ** \\
\hline AP & 1.92 & 0.00267 & 0.00828 & -0.000196 \\
\hline CCC & 6.84 & $0.0300 * * *$ & -0.0117 & 0.0139 \\
\hline Dummy & 1.19 & 0.0256 *** & 0.00118 & 0.00608 \\
\hline CAT & 3.89 & 0.0525 *** & $0.0536 * * *$ & 0.0448 \\
\hline CR & 1.52 & $-0.00395^{* * *}$ & -0.000605 & -0.00148 \\
\hline LEV & 1.76 & $-0.213^{* * *}$ & $-0.213^{* * *}$ & -0.138 \\
\hline SZ & 1.66 & -0.00000393 & $-0.0191^{* * *}$ & -0.00533 \\
\hline GR & 1:04 & -0.00789 * & -0.00393 & -0.00441 \\
\hline Cons & & 0287 ** & 0768 *** & $0597^{* * *}$ \\
\hline \multirow[t]{2}{*}{$N$} & & 403403 & & 403 \\
\hline & & 0435 & 0365 & \\
\hline $\begin{array}{l}\text { R-sq- } \\
\text { significance }\end{array}$ & & $\begin{array}{l}\mathrm{F}(10,392) \\
=30.22\end{array}$ & $\begin{array}{c}\mathrm{F}(10.355) \\
=20: 42\end{array}$ & $\begin{array}{c}\text { Wald chi2 } \\
(10)=219.13\end{array}$ \\
\hline White test & & \multicolumn{2}{|c|}{$\begin{array}{r}\text { Chi2 }(64)=213.24 \\
0.0000\end{array}$} & Prob $>$ Chi2 = \\
\hline LM test & & \multicolumn{3}{|c|}{$\begin{array}{r}\text { Chibar2 }(01)=794.55 \\
\text { chibar2 }=0.0000\end{array}$} \\
\hline $\begin{array}{l}\text { Hausman } \\
\text { test }\end{array}$ & & \multicolumn{2}{|c|}{$\begin{array}{r}\text { Chi2 }(10)=12.67 \\
0.2428\end{array}$} & Prob $>$ chi2 = \\
\hline $\begin{array}{l}\text { Wooldridge } \\
\text { test }\end{array}$ & & \multicolumn{2}{|c|}{$F(1,37)=80.729$} & $b>F=0.0000$ \\
\hline
\end{tabular}

Note: $\left.\left({ }^{*}\right),\left({ }^{* *}\right),{ }^{* * *}\right)$ represent for the significant level at $1 \%, 5 \%$ and $10 \%$, respectively.

Table 4: GLS regression results of model

\begin{tabular}{|l|c|c|}
\hline Variable & $\begin{array}{c}\text { Model 1 } \\
\text { (ROA) }\end{array}$ & $\begin{array}{c}\text { Model 2 } \\
\text { (GOP) }\end{array}$ \\
\hline INV & -0.00483 & -0.0083 \\
\hline AR & $-0.0230^{* * *}$ & $-0.0254^{* * *}$ \\
\hline AP & $0.00976^{* * *}$ & -0.0002 \\
\hline CCC & $0.0138^{* *}$ & 0.0139 \\
\hline Dummy & $-0.00593^{*}$ & $-0.00608^{*}$ \\
\hline CAT & $0.0192^{* * *}$ & $0.0488^{*+*}$ \\
\hline CR & -0.00144 & -0.00148 \\
\hline LEV & $-0.118^{* * *}$ & $-0.138^{* * *}$ \\
\hline SZ & 0.00216 & -0.00533 \\
\hline GR & $0.0054^{* * *}$ & $-0.00421^{*+*}$ \\
\hline cons & 0.0469 & $0.393^{*+*}$ \\
\hline
\end{tabular}

Note: $\left({ }^{*}\right),\left({ }^{* *}\right),\left({ }^{* * *}\right)$ represent for the significant level at $1 \%, 5 \%$ and $10 \%$, respectively. 


\section{Recommendations and Conclusions}

Liquid assets are an important part of generating profits for economic groups, accounting for more than $60 \%$ of total assets of listed companies for the period 2009 - 2019, Likewise, the accounts payable are an important source of funding for Vietnamese businesses in general and listed economic groups in particular in underdeveloped capital markets like Vietnam. Policy on investment and management of liquid assets as well as use of payables have an important impact on business performance.

This study has been performed on financial data of 38 economic groups listed on the Vietnamese stock market for the period of 2009 - 2019 to provide an empirical evidence of the impact of capital management policy and its working efficiency in all stages of the economic cycle of Vietnamese economic groups. Research shows that the greater the level of investment by companies in liquid assets corresponding to a certain level of activity (shown by average days of inventory (INV), average days of collection. (AR), and the cash flow cycle (CCC), the lower will be the rate of return on assets, and conversely if the control on the working assets is good, if the average number of days of inventory is shortened, then days of collection and the cash flow cycle increases the return on assets. On the other hand, a negative relationship between the number of payable days (AP) and performance has been observed, suggesting that firms with low performance are more likely to pay their accounts payable more slowly. The study also provides additional evidence of the negative effects of economic crisis on the performance of economic groups. The study also shows that the number of short-term asset cycles has a positive impact on operational efficiency, and the level of debt use has a negative impact on operational efficiency. This result implies that the managers of economic groups can increase the efficiency of businesses, creating added value for investors through a reasonable working capital policy.

\section{References}

Ali, A., \& Faisal, S. (2020). Capital Structure and Financial Performance: A Case of Saudi Petrochemical Industry. Journal of Asian Finance, Economics, and Business, 7(7), 105-112. https://doi.org/10.13106/jafeb.2020.vol7.no7.105.

Deloof, M. (2003). Does working capital management affect profitability of Belgian firms? Journal of Business, Finance and
Accounting, 30(3-4), 573-587. https://doi.org/10.1111/14685957.00008 .

Dong, H. P., \& Su, J. T. (2010). The relationship between working capital management and profitability: a Vietnam case. International Research Journal of Finance and Economics, 49(1), 59-67. http://www.eurojournals.com/finance.htm.

Enqvist, J., Graham, M., \& Nikkinen, J. (2014). The impact of working capital management on firm profitability in different business cycles: Evidence from Finland. Research in International Business and Finance, 32, 36-49. https://doi. org/10.1016/j.ribaf.2014.03.005.

García-Teruel, PJ \& Martínez-Solano, P. (2007). Effects of working capital management on SME profitability. International Journal of Managerial Finance, 3(2), 165-177. https://doi. org/10.1108/17439130710738718.

Horne, JCV, \& Wachowicz, JM (2008). Fundamentals of financial management (13 ${ }^{\text {th }}$ ed.). Upper Saddle River, NJ: Prentice Hall.

Lazaridis, I. \& Tryfonidis, D. (2006). Relationship between working capital management and profitability of listed companies in the Athens Stock exchange. Journal of Financial Management and Analysis, 19 (1), 1-12. https://ssrn.com/abstract=931591

Merville, L. J., \& Tavis, L. A. (1973). Optimal working capital policies: A chance-constrained programming approach. Journal of Financial and Quantitative Analysis, 8(1), 47-59. DOI: $10.2307 / 2329747$

Mielcarz, P., Osiichuk, D., \& Wnuczak, P. (2018). Working capital management through the business cycle: Evidence from the corporate sector in Poland. Contemporary Economics, 12 (2), 223-237. https:// go.gale.com/ps/anonymous?id=GALE\%7CA570046810\& sid=googleScholar\&v=2.1\&it=r \&linkaccess=abs\&issn=208408 $45 \& \mathrm{p}=\mathrm{AONE} \& \mathrm{sw}=\mathrm{w}$.

Oseifuah, E. (2018). Global financial crisis, working capital management and profitability of non-financial firms listed on the Johannesburg Stock Exchange, South Africa. Academy of Entrepreneurship Journal, 24(3), 1-12. https://search.proquest. com/openview/8b2eac208f09a7bc2c5667d5633fd9fc/1?pqorigsite $=$ gscholar $\&$ cbl $=29726$

Pattiruhu, J. R., \& Paais, M. (2020). Effect of Liquidity, Profitability, Leverage, and Firm Size on Dividend Policy. Journal of Asian Finance, Economics and Business, 7(10), 35-42. https://doi. org//jafeb.2020.vol7.no10.035

Pham K. X., Nguyen, Q. N., \& Nguyen, C. V. (2020). Effect of Working Capital Management on the Profitability of Steel Companies on Vietnam Stock Exchanges. Journal of Asian Finance, Economics and Business, 7(10), 741-750. https://doi. org//jafeb.2020.vol7.n10.741 